Katarina Eriksson Barajas

\title{
Discursive Reception Studies - A Path toward Knowledge about Fiction in Everyday Life
}

\begin{abstract}
The study of mainstream consumers of fiction is still limited, as is research of naturalistic reading situations. In this paper I argue that a combination of reception theory and discursive psychology - discursive reception research - can be a fruitful method for empirical literary studies. Reception theory gains both a way to adequately analyze conversations about literature (and other aesthetic products), and the opportunity to study how the reception is done and how literature is used, while discursive psychology, in turn, gains the opportunity to »dementalize« a practice that has previously been surrounded by a strict cognitivist paradigm. Literature and other aesthetic products such as film and theater often deal with existential questions. In this way, conversation data on aesthetic reception provides a greater breadth of such content than does other natural conversation data. I argue that discursive psychology provides systematic tools and concepts for analyzing talk that can be useful for literary scholars who mostly deal with fiction. In addition, discourse analysis of conversation transcripts resembles the analysis of literary texts, making talk seem less alien to analyze for those who are accustomed to studying written text. The analytical tools used in discursive psychology thus provide literary scholars with adequate help for the analysis of conversations. The advantage of using discursive psychology and discourse analysis when researching reception is that a detailed analysis of the interaction reveals how participants create a shared reading of literature (Fish 1998). In much of the previous reception research, the researcher has only considered the respondent's answer and not how the answer, or the reading, emerges in the conversation. In some examples, I show how an interactional focus on booktalk enables us to highlight children's voices as part of a common social practice, for example in a discussion about withdrawing when one is feeling sad. I also show how the booktalk participants refer to traditional gender positions in a conversation about the characters in a book. I show how a teacher presents his own hypothesis about people from other parts of the world in booktalk. My hope is to add another dimension and in this way highlight the importance of teachers taking careful consideration when they use fiction - books as well as film - in an attempt to create contrasting images to undemocratic
\end{abstract}

Katarina Eriksson Barajas: Department of Behavioural Sciences and Learning, Linköping University, Sweden, E-Mail: katarina.eriksson.barajas@liu.se 
conditions, as the Swedish school curriculum requires. In addition to the experiences conveyed in the conversations, I also show examples of how people in conversation about literature can position themselves as, e. g., a booklover, a guy or as enlightened. This type of analysis also gives insights into how booktalk reception is done. Detailed analyses of conversations about books provide opportunities to study the connection between fiction and life. In this way, our knowledge of literature in practice increases, allowing us to address questions such as: How is literature used to create ourselves and position others, to portray us as good or well-read, as belonging to the cultural elite or as not being a snob? How can discussions about literature be used to quarrel, flirt, make friendships, etc.? How are the concepts >reader and `non-reader construed in young people's identity work?

DOI 10.1515/jlt-2015-0002

Throughout history and across cultures, humans have created and experienced fiction. The present paper investigates a methodology designed to increase our knowledge of the everyday use of fiction. ${ }^{1}$ People of all ages consume books, films and theater through different media and a variety of practices. After or during such consumption of fiction, people sometimes tell each other about their experiences. Other practices surrounding fiction are shared experiences - for example going to the cinema or the theater. Talk about books, films and theater is a living conversational practice. Reader-response research is conducted to investigate how people take up stories. In this field, knowledge about what readers understand, realize and experience while reading or consuming other fiction is sought. By studying the conversations that occur naturally around mediation of fictive narrative, the researcher can contribute new insights into some of the issues examined in reception research.

\section{Reader-oriented research}

The basic assumption of all reader-oriented research is that the reader is a cocreator of the text. This can be studied in a wide range of manners: from studying the rhetoric and the "reader « in the text or studying a text's impact on authentic readers. The two main research approaches that focus on the reader are reader-

1 Parts of the paper have been published in a book chapter written in Swedish (Eriksson Barajas 2007). 
response criticism and reception theory. Wolfgang Iser distinguishes reception from response in that "[a] theory of response has its roots in the text; a theory of reception arises from a history of readers' judgements « (1978, x).

Etymologically, reception derives from the Latin, receptiõ, which means the act of receiving (Onions 1966, 745). Reception theory has been thoroughly presented by Robert C. Holub in Reception Theory: A critical introduction (1984). The purpose of Holub's book was to introduce German reception theory to a non-German-speaking audience (ibid., xiv). Holub began by sorting out the boundaries between the two approaches; the connection is that they share an involvement in the general shift from author and work to text and reader. The major divergence, according to Holub, is that reception theory started as a collective undertaking, while readerresponse criticism constitutes a more loosely connected group, a catch-all term for a group of separate theories (ibid., xii). In this regard, it is not so surprising that some theorists, for example, Iser, appear in both the field of reception theory and that of reader-response criticism.

Besides Iser, Jauß is one of the major theorists in reception theory. Jauß has had an impact on literary theory through his formulation of a history of readers' reactions to literature, focusing on the general reception of literature during a certain epoch. According to Holub, Jauß' interest in reception derived from his attention to the connection between literature and history. Another of Jauß' important contributions to literary theory is the notion of horizon of expectation (1982, 22). The reader has expectations of the book and reads the book through these expectations; the reader will be satisfied if these expectations, or some of them, are fulfilled. Also, the thoughts and ideas that are presented to the reader in the book can change the readers' horizon of expectation. Masterpieces have had the power to change ingrained patterns. These »classical« masterpieces, which form parts of the literary canon, will continue to be relevant, and they will influence generation after generation. Each generation interprets them anew based on their experiences. Methodologically, the distinct receptions of different historical generations are studied through critics, reviews, diaries, cultural articles and so on. One can also come across the notion Rezeptionsästhetik (German; >aesthetics of reception`) for this branch of reception studies.

In the present paper, I argue for additional, in-depth knowledge that can be provided by a combination of reception research and discursive psychology. I have previously called this approach discursive reception research (Eriksson Barajas/Aronsson 2009; Eriksson Barajas 2007). Such an approach allows the researchers to analyze the interaction involved in the construction of a specific reading of a book. By reporting and analyzing in detail, the whole dialogue, not just the reader's responses, the researcher can acquire knowledge about the everyday practices of fiction. 


\section{Empirical approaches on reception and reader- response}

Empirical research on literary reading can be conducted in different ways. Daniel Allington and Joan Swann (2009) divide the general field into roughly four traditions: 1) empirical literary studies, which mainly uses experimental methods; 2) media reception studies, a subfield of cultural studies; 3) ethnographic studies of reader practices; and 4) studies of history of reading. Of these, I will be discussing 2 and 3, as they are relevant to the discursive psychology approach. Only the first tradition is called empirical, although all four traditions use empirical data in the sense of observations or experience rather than theory. Allington and Swann (2009, 224) argue that:

Psychological experiments on literary reading, with their sthink aloud protocols, their rating tasks, their tests of recall, etc. - not to mention the exam-like environments in which they often take place, and the bibliographically idiosyncratic texts (or stextoids $`$ ) at their heart might be thought signally unsuited to the task of building up a model of sordinary reading .

The bulk of the research on reception is based on experimental studies in which the researcher has staged reception.

Jonathan Potter, Peter Stringer and Margaret Wetherell (1984) advocate an interactionist perspective on literary studies to emphasize literature's social and political context. Combining reception research with discursive psychology can be seen as a continuation of their work, as the combination investigates conversation practices in relation to literature. In the 1980s, the field of Media Reception Studies included, for example, studies of television viewing in people's homes.

Among the ethnographic studies, a subfield is forming in which a discourse analytic approach to reception data is used, starting with Joke Hermes (1995). Her goal was to »understand how women's magazines become meaningful for readers in the context of their everyday lives« (ibid., 176). In 80 interviews, Hermes analyzed readers' interpretive repertoires, drawing on the notion of interpretive repertoires as defined by Potter and Wetherell (1987). In a study of naturally occurring book clubs in school, discursive psychology was used in a reception study some years after Hermes' study (Eriksson 2002a).

Within discursive psychology, the researcher aims at enhancing the study of naturally occurring interactions. Here, "naturally « is used to denote practices that would have been going on regardless of whether they were being researched, as opposed to practices that are initiated by researchers, such as interviews. In this approach, "naturally« is not used as a synonym to »spontaneous, pure, authentic« (see, e. g., the chapter »On >natural« data« in Eriksson 2002b for references 
and a more detailed account). Studying natural interaction enables the researcher to see how for example children, in everyday situations, learn to interpret and analyze books and movies, what it gives them, and what they think is important and interesting to take up.

Children use fiction in a number of ways in everyday life; one literary practice, among others, for children is controlled reading activities at school. Excerpts 2-5, below, are taken from a Swedish book club that aimed at turning as many pupils as possible into bookworms. The school staff chose the books, assigned pupils to groups and led the booktalks just as they normally would have done. When the talks were conducted in the groups, I set my video camera, and in some case the microphone, and left the room. The participants were aware that they were being filmed, which influenced the book talks, but the point is that the activity was not governed by the researcher but carried out by »the usual« participants. By adopting a discursive perspective, what emerges, beyond the direct response, is also how participants in conversation about books create themselves and interact with others.

\section{Methods of analysis}

By analyzing ethnographic stexts (conversation, interactions and images) in detail, a dual focus is placed on interactional resources and sequential practices as well as on the discourses utilized by participants. Validation of analyses is accomplished by studying participants' uptake of and orientation toward prior positioning in conversations or texts (Sacks/Schegloff/Jefferson 1974). These are key methodological principles that discursive psychology has taken from Conversation Analysis and ethnomethodology and are argued to anchor the analysis in the participants' own perspectives on the interactions. Analyses of deviant cases are also vital to discursive psychology, as are sequential analyses of coherence across utterances and episodes. Moreover, the presentation of detailed transcriptions in publications allows other analysts to evaluate and re-evaluate the material (Hepburn/Potter 2004, 190). Recorded interactions are transcribed, using notion systems such as discursive variation and rhetorical organization.

To illustrate the differences in methodologies when analyzing data, I have taken an interview excerpt from an ethnographic study of literature in the school (Molloy 2002). First, I discuss the unfolding of the interview drawing on Molloy's analysis and then I analyze it from a discursive psychology perspective. In the excerpt, the researcher (J) discusses reading with Edward who is attending high school at the time of the interview. 


\section{Excerpt 1:}

J: You don't read very much, huh?

E: No, I don't.

J: Do you know any guys who do?

E: Um, no, nobody that I know reads a lot. No, not really. There are some who read more than me, but not so very much.

J: Huh, isn't it manly to read books?

E: I don't know. Maybe reading books doesn't appeal to guys.

$\mathrm{J}$ : What is it then that appeals to guys instead?

E: Uh, it's video games and computers and various sports and stuff.

(Molloy 2002, 135, my translation)

In her analysis of the conversation, Molloy argues that »Edward describes himself as a guy in a guy group. Constructing gender as an individual in this collective is done [...] through active deeds such as playing sports together or playing computer games in a group." (Edward beskriver här sig själv som en kille i killkollektivet. Att som individ konstruera kön i detta kollektiv sker [...] genom aktiva handlingar som att idrotta tillsammans eller spela dataspel ihop. [ibid., my translation])

From a discursive perspective, what emerges when analyzing the reproduced excerpt is how reading is made into a gender marked activity in the conversation: "Do you know any guys who do?« Using what could have been said as an analytical lever (Potter 2003, 616), we see that the interviewer might have asked whether Edward had a friend who reads a lot. In that case, reading would not have been made into a gender issue. Because the interviewer relates to gender, using the notion that guys do not read much, she positions Edward as belonging to a male collective, without Edward ever having made any claim to that effect in the interview excerpt. The interviewer continues to relate to gender in the next question by linking manliness to rejection of book reading. In the two following turns, Edward and the interviewer create a picture of guys having some shared things that are not appealing to them and other shared things that are appealing to them. After some hesitation, Edward finally enumerates a few things that are appealing to guys. It would have been interesting to see the turns that followed as well; did they perhaps reveal that guy things should be carried out in a group? Or is this Molloy's own gender-colored construction of guys who collectively play sports »together" and play computer games »in a group«? In addition to the knowledge Molloy's (2002) study adds about reading in school, the example also provides, from a discursive perspective, unique insights into how reading can be made into a matter of gender in a conversation.

The discursive perspective focuses on the conversation, in this case between a researcher and a student, and the conversation is collaboratively produced not only on a person's (the student's) response to another person's (the researcher's) 
questions. Therefore, taking a discursive psychology perspective generates knowledge concerning how conversations about reading create gender and fill it with content. In this conversation, Molloy's interview questions constructed reading as something non-masculine, while sports and computer gaming become male activities. Masculinity is further construed in terms of doing things together. The group aspect is supported indirectly when it is pitted against reading, which is often viewed as a solitary activity.

If the researcher, for example, is studying how young people talk about books in a pedagogical context such as school, beyond adding knowledge of what young people talk about, additional phenomena may also emerge, such as how the teacher may be pushing a particular moral agenda. In a study of how »the Other « is created in booktalk, discursive analysis reveals the teacher's promotion of a moral agenda of realizing that "we« Western children are privileged compared to people »down in Africa « (Eriksson/Aronsson 2005). Without a discursive analysis of the institutional practice - booktalk in school - it would not be possible to see this (see for example Hepburn/Wiggins 2005, 597-598).

Excerpt 1 shows how discursive psychology can enrich reception research, but what can drawing on both approaches bring to the field of discursive psychology? By collecting and analyzing booktalk, insights into various phenomena, such as preconceptions about gender, age and strangers, can be generated and dealt with in a »natural « conversational environment (see, e. g., Potter 2005, 744). By consistently using discursive psychology to conduct reception research both approaches to the genuinely interdisciplinary field are enriched: Reception research can systematically and adequately collect and analyze conversation data while discursive psychology gets at »natural« data from previously unexplored practices.

\section{Discursive psychology}

Discursive psychology has been influenced strongly by the conversation analytic approach to social interaction. The leading scholars of discursive psychology, Derek Edwards and Jonathan Potter, emphasize that a starting point for this theoretical perspective is that the researcher treats text and talk as social practices (Edwards/Potter 1992). Discursive psychology involves a qualitative research approach. The research questions raised in discursive psychology have the form How is $X$ done? (Potter 2003). Thus, questions about the »inner « reasons or motives for people's interactions are not investigated. Only what can be studied in the displayed interactions is considered. The research questions are, thus, empirically driven. Studies in the field typically relate to conversations within institutional settings. By studying the conversation in detail, the researcher captures the dual 
focus that discursive psychology applies to the studied practice, on the one hand, and to the structural resources - such as patriarchal structures - that participants in the practice use, on the other. Validation of the analysis is done by studying the participants' orientation to the statements in the conversations, deviating cases, coherence of statements and by providing detailed transcriptions along with the analysis so that the reader can get an idea of the material (Hepburn/Potter 2004).

Discursive psychology provides systematic tools and concepts for analyzing talk that can be useful for literary scholars who mostly deal with fiction. In addition, discourse analysis of conversation transcripts resembles the analysis of literary texts, making talk seem less alien to analyze for those who are accustomed to studying written text. The analytical tools used in discursive psychology thus provide literary scholars with adequate help for the analysis of conversations. The advantage of using discursive psychology and discourse analysis when researching reception is that a detailed analysis of the interaction reveals how participants create a shared reading of literature (Fish 1998). In much of the previous reception research, the researcher only has considered the respondent's answer and not how the answer, or the reading, emerges in the conversation.

Studying booktalk as interaction helps us understand the action potential in the interpretation of literature; participants in a conversation about a book or movie not only report their individual reading of a story - in the conversation they also show how they use their interpretation in social interaction. This allows us to analyze how the readings are created in social interaction and how they are used for different purposes in the interaction. In this way, our knowledge of, for example, fictional characters, is made more dynamic.

Below, I illustrate, using analytic examples, the opportunities that discourse psychology offers for understanding literature reception. Excerpts $2-5$ are drawn from a larger dataset: a discursive study of reader responses in a naturalistic school context, so-called book circles (Swedish: läsecirklar), that involved a teacher and between three and eight pupils in grades 4-7 (aged 10-14 years). With the bookclubs, the school wanted to make as many pupils as possible become »bookworms«. Each group of pupils met with their teacher on three occasions, as part of regular school activities, reading aloud from and discussing a book that they had chosen from a set of books presented by a teacher-librarian. All discussions were led by one of the teachers, who was inspired by Chambers' reasoning on "booktalk» and his basic idea that you have not properly read a book until you have discussed it with somebody else (Chambers 1999). Chambers' aim is to help children enjoy books.

During one academic year, I video-recorded 24 booktalk sessions, involving eight different groups and three sessions per group. In all, 40 pupils (20 girls and 20 boys) and 5 teachers ( 4 females and 1 male) participated. However, it is 
the booktalk practices in which these people participated that constitute the primary analytic units of the present study. In order to investigate the reading responses, the book club sessions were recorded in their entirety. I followed the recommendations of Potter and Wetherell (1995), making in extenso transcriptions of the entire dataset (in all about 450 A4 pages).

The first example illustrates how students discuss the relationship between the book's text and their everyday life. The analysis of the second example shows how a reading-circle conversation about a gender-transgressive book can end up producing stereotypical gender ideas and positions. The third example shows how participants in a book club collectively construct images of the Other, namely of alienation. The final example shows the creation of different reader positions.

\section{The pupil's voice in interaction}

In the first example, a boy, Sten, responds in a concrete manner to an abstract question. Sten's group (Grade 6) has been reading Secrets in the Fire (Mankell 2000) which is set in Mozambique. The main character, Sofia, her sister Maria, and their mother are internal war refugees. By accident, Sofia steps on a land mine and loses both legs, her sister dies in the explosion. (For an explanation of the transcription symbols, see Appendix A.)

Excerpt 2: Book club 6A: $2^{2}$ Secrets in the Fire, Tape 11:0.56.15. Participants: MARY (teacher), Lena, Gerd, Rut, Siv, Dora, Bo, Paul, Sten

\begin{tabular}{|c|c|c|}
\hline 1. & MARY: & $\begin{array}{l}\text { so that the- there were lots of thoughts going through her ((referring to Sofia, } \\
\text { the main character in the text)) head and sometimes she sat down and pulled } \\
\text { the blanket over her head and refused to eat and didn't want to answer (.) } \\
\text { why do you think she did this? }\end{array}$ \\
\hline 2. & Sten: & well she be- she thought it was her fault that Maria ((her sister)) was dead \\
\hline 3. & Bo: & ${ }^{\circ}$ she wanted to be invisible ${ }^{\circ}$ \\
\hline 4. & MARY: & yes, Bo what did you say then? \\
\hline 5. & Bo: & she wanted to be invisible \\
\hline 6. $\rightarrow$ & MARY: & $\begin{array}{l}\text { and it was probably at times like this when she- we usually say that people are } \\
\text { depressed, they don't want to talk to anyone (.) when you don't want to talk to } \\
\text { anyone, when you feel like ugh! everything's so hard now what do you all do? }\end{array}$ \\
\hline 7. & Dora: & I sit quietly \\
\hline & Rut: & shut myself in my room \\
\hline
\end{tabular}

$26 \mathrm{~A}: 2=$ grade 6 , group $\mathrm{A}$, second of three sessions 


\begin{tabular}{lll}
\hline 9. & Sten: & I can't \\
10. & MARY: & you can't \\
11. $\rightarrow$ & Sten: & we have lots of flexes from my room so you can't shut the door
\end{tabular}

In turn 6, the teacher makes a text-to-life reference (Cochran-Smith 1994) where everyday life is actualized by the text. One purpose of the text-to-life references is to teach pupils to use texts to better understand their own lives. In this case, the link is made through a description of the fictional Sofia's behavior to invoke students' own experience of not wanting to talk to someone when you feel sad. Both Dora and Ruth share their experiences of shutting themselves in their room, while Sten (Turn 9 and 11) says he cannot because there are too many wires pulled through his doorway. The sensitive discussion of complex emotions, thus, leads to a question of concrete barriers. Sten shares his personal problems - he finds it difficult to withdraw because he cannot close the door to his room. One can also see Sten's manner of answering in this very concretely as a sign of resistance to the obtrusive issues (Eriksson/Aronsson 2004). In any case, the teacher's reaction to Sten's answer is not to continue pushing him with follow-up questions - in the follow-up round, she turns to someone else. As the example shows, what counts as a text-to-life reference in a reading circle requires interaction - it is only possible if both parties choose to relate both to the text and to life outside the text.

\section{Gendering the booktalk}

The following example describes how participants in a book circle in school make gender relevant.

Excerpt 3: Book club 4B:2. Smuggelkatten (Ekholm 1990). Tape 3: 1.03.46. Participants: SUE (teacher), Julia, Sara, Mia, Ida, Dan (Eriksson Barajas 2008, 135-136).

\begin{tabular}{|c|c|c|}
\hline $\begin{array}{l}1 . \\
2 .\end{array}$ & SUE: & $\begin{array}{l}\text { Would any of you like to be Anna? be like Anna? } \\
\text { ((Sara and Mia raise their hands. Julia raises her hand too.)) }\end{array}$ \\
\hline 3. $\rightarrow$ & SUE: & Yes all the girls \\
\hline 4. & Mia: & She has such a kind dad \\
\hline 5. & Sara: & l'd also like to be like Anna ((Chuckling.)) \\
\hline 6. & SUE: & $\begin{array}{l}\text { You'd like that yes ((Turns towards Dan.)) who would like to be? Would you } \\
\text { like to be like [Per the bird]-watcher? }\end{array}$ \\
\hline$\rightarrow$ & Dan: & [The cat!] \\
\hline
\end{tabular}


8.

9. SUE: Live a spoiled life you mean? I can see that uh: so you like that kind of food (.) liver paté and sardines and whatever the cat?

10. Dan: Nope only tuna

11. SUE: You like tuna

12. Sara: Hehe

13. SUE: Then you could be a kitty-cat in that way uh hu

14. Dan: And prawns

15. SUE: Yes that's not bad that's not bad

The teacher initiates the students' identification with the main character, Anna (Turn 1). Three of the four girls in the group raise their hands. The teacher's interpretation of their response (»yes all the girls«) orients toward gender through the underlying assumption that Sara, Mia and Julia would like to be or be like Anna because they themselves are girls (Turn 3). When the teacher says that all girls wanted to be like Anna, she ignores the fact that Ida did not raise her hand; she does not ask Ida whom in the book she would like to be like. The teacher obviously presupposes that all the girls want to identify themselves in the same way because they are members of the same sex. The teacher also assumes that students identify with same-sex characters. In the following, we see how the teacher assumes that Dan would like to be like a male character.

Instead of asking Ida which of the characters she would like to be, the teacher turns to Dan, the group's only boy, asks whom he would like to be like, and suggests the birdwatcher Per (Turn 6). Dan replies that he would rather be the cat (Turn 7). Until the moment when the teacher and Dan fall each other in the speech, the main character Anna has been in focus. I argue that the teacher creates a gender issue with her statement in Turn 3 - that all the girls would like to be like Anna despite the fact that one of the girls does not respond. This interpretation is supported by the teacher's way of turning to the group's only boy, Dan, to find out whom he would like to be (Turn 6). There is no important male character available for Dan to choose. And the teacher indicates in turn 6 that the character Anna is not available to him, which means further orientation toward gender. As a consequence, Dan says that he would like to be the (male) cat, who is an important character, rather than the girl, even though she is the main character.

Dan's expressed wish to be like a (male) animal rather than like a girl is consistent with earlier research. In a study of 6- and 8-year-old children's readings of a story on television, Ingegerd Rydin $(1996,174-175)$ showed that a majority of her informants identified with the same-sex characters. This was also the case for the children in Bronwyn Davies' fairytale study $(1989,230)$. Judith A. 
Howard and Carolyn Allen $(1989,296)$ argue that because most stories have a male narrator, boys do not get training in gender cross-identification when they read. Excerpt 2 shows how the teacher and several students reflect on and create gender congruence between the reader and the book characters that can serve as potential ideal.

\section{Construction of »us» and »the Others»}

In the following example, an analysis is presented of how »us « and »them « are construed based on whether the »Others « are literate; language and literacy are key issues when »us« and »them « are construed. The story discussed is set on an isolated island. The islanders have pushed away the main character because he is a deaf mute.

Excerpt 4: Book club 7B:2: The Silent One (Cowley 1981), Tape 6:0.44.51. Participants: ALAN (teacher), Pia, Lisa, Elias, Ulf, Nils, Klas (Eriksson/Aronsson 2005, 725-726).

\begin{tabular}{|c|c|c|}
\hline 1. & ALAN: & The people living $\uparrow$ on this island $\uparrow$, in this \\
\hline 2. & & environment, they're not very- do you think \\
\hline 3. & & they can <read and write> and they usual- \\
\hline 4. & Pia: & Azaki- ki can \\
\hline 5. & ALAN: & Yes, exactly. But he's pretty much the only \\
\hline 6. & & one, isn't he? \\
\hline 7. & Several: & Uh huh \\
\hline 8. & ALAN: & (3) But the people living on the island, \\
\hline 9. & & they've only seen what's there. \\
\hline 10. & Klas: & Yeah \\
\hline 11. & ALAN: & They have their own ideas they can \\
\hline 12. & & never read about if other people have- they don't \\
\hline 13. & & often meet other people. \\
\hline 14. & Pia: & Uh huh \\
\hline 15. & ALAN: & Or what? \\
\hline 16. & Klas: & Yeah \\
\hline 17. & ALAN: & So it might be a bit hard for them to think in \\
\hline
\end{tabular}


In line 2, the teacher Alan starts an evaluation of the islanders in the book under discussion, sthey're not very-८, where he focuses on a perceived disparity, which can be seen as a shortcoming. The teacher interrupts himself and asks instead if the islanders can read and write. In other words, the teacher reformulates a prejudice to make it a question. The pupil Pia argues against the teacher's generalization and says that >Azaki< (i.e., Aesake), one of the protagonists, actually can read and write (Line 4). Alan's response (Line 5-6), that Aesake is essentially the only one who is literate, can be seen as an »extreme case formulation « (see Edwards 2000). The statement is one way to minimize the importance of what Alan may be seeing as a problematic exception. Some students respond to Alan's utterance in a minimal way >Uh huh` (Line 7). Then the teacher talks about the islanders' limited experience of the world (Line 8-9 and 11-13). When the teacher is satisfied that at least one student agrees (Line 15), he sums up by stressing that the islanders' limited experience (and their illiteracy) explains why they cannot think in ways other than how they think. Thus, according to the teacher, it is the combination of living in an isolated place and being illiterate that makes the islanders limited in their thinking. Indirectly, the teacher advocates reading and writing skills as a way to offset geographic isolation.

\section{Reader identities}

In one of the booktalk sessions, reader identities are implicitly invoked when the teacher and pupils jointly discuss time for reading.

Excerpt 5: Book club 6B:1.3: Nonni och Manni (Svensson/Telemann 1989). Tape 12: 0.16.13. Participants: BRITT (teacher), Sonja, Vicky, Max, Tobbe (Eriksson Barajas/Aronsson, 285).

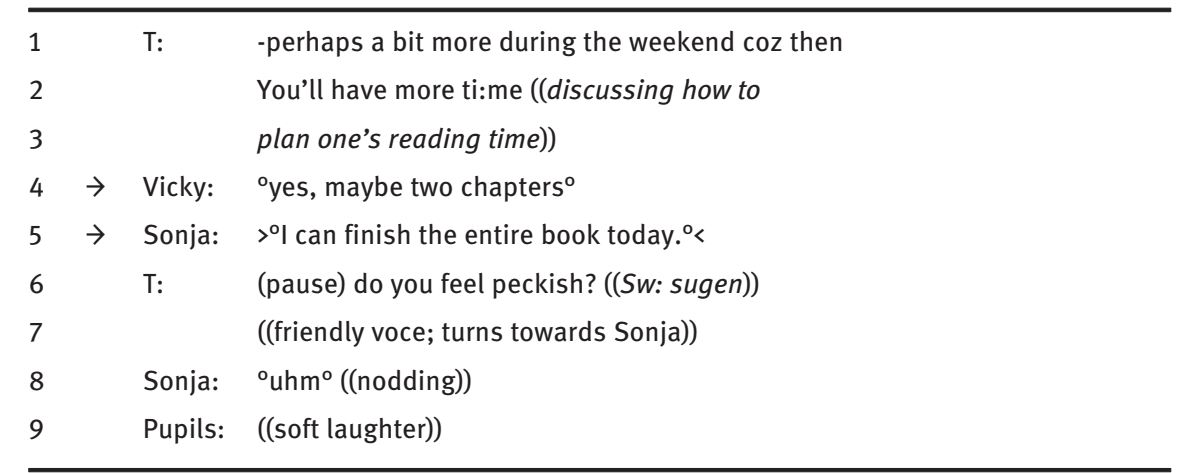


The teacher (Lines 1-2) has been discussing when the pupils are supposed to read the assigned book, suggesting that they might read a bit more of the book during the weekend. In sotto voce, Vicky spontaneously comments that she will probably be able to read two chapters (Line 4). Sonja continues but indirectly outperforms Vicky in that she reveals that she would be able to read the entire book on that very day (Line 5). The teacher chooses not to comment on the two girls' contrasting projected reading abilities, or on the idea that Vicky will only be able to finish two chapters of a children's book during an entire week, including the weekend. Instead, she turns to the fast reader Sonja, asking her »känner du dig sugen?« (Line 6), which literally means »do you feel peckish?« (or »are you hungry?«) - a question that is quite in line with the overall food metaphor of bokslukare (devourer of books). Someone who is a book devourer is also bound to feel a hunger for books. The teacher's comment can be seen as a type of repair work in that she focuses on Sonja's high motivation to read or delight for books, thereby reinterpreting what could have been seen as bragging on the part of a high-speed reader. Fast reading is thus reinterpreted in terms of high reading motivation (love of books), instead of in terms of high achievement or bragging.

\section{Discussion}

In an editorial in the premiere issue of Scientific Study of Literature, Peter Dixon and Marisa Bortolussi (2011) present a comprehensive collection of ideas about what can and should be done in the field of empirical methods in literary studies (where literature is understood in a broad sense, including film and theater). The study of mainstream consumers of fiction is still limited, as has been pointed out by, for example, Swann and Allington, who argue "that reading groups provide an example of how >ordinary readers $-i$. e. readers other than academic critics and professional reviewers - interpret and evaluate literary texts« $(2009,247)$. Moreover, as Dixon and Bortolussi (2011) point out, a broader understanding of literature in context is lacking. Dixon and Bortolussi (ibid., 68) suggest that the "greatest challenge is the development of theories of the reader in context«. Learning more about literary practices would increase our ability to understand literature in society (ibid., 69). I would like to suggest adding a subcategory to their collection of »Tools for understanding context«; Tools for understanding literary practices. Willie van Peer also emphasizes a lack in knowledge of the role of literature »in the lives of individuals and social groups « $(2011,1)$. I would like to emphasize a focus on the practice part of context: How, where, and in order to meet what needs and derive what pleasures do we use fiction in everyday life? 
In this paper, I have investigated how applying a discursive psychology approach to empirical reception data - discursive reception research - can be a fruitful method for empirical literary studies. The examples show how an interactional focus on booktalk enables us to highlight children's voices as part of an everyday social practice, for example, in a discussion about withdrawing when one is feeling sad (Excerpt 2). We have also seen how the participants refer to traditional gender positions in a conversation about the characters in a book (Excerpt 3). I showed how a teacher presents his own hypothesis about people from other parts of the world in booktalk (Excerpt 4). Lastly, a co-construction of an avid reader is displayed (Excerpt 5).

The school syllabus for Sweden reflects the prevalent notion that fictitious narratives are important for identity development and processing of life's major issues. School is one setting where children and young people are given opportunities to discuss the stories they read or experience through film and theater. The school's literature discussions constitute living conversation practice. To find out how children and young people acquire stories, reception and reader-response research is carried out. By studying what students and teachers do - specifically their interaction - when they are »doing reception « in social interaction at school, we can get answers to questions concerning how the reader can use the insights and experiences that literature offers, and what literature conversations can be used for. To study human interaction around reading literature in an adequate and systematic way, reception research's interest in narrative interpretation needs to be combined with discursive psychology's focus on conversation and interaction.

My hope is to add another dimension and in this way highlight the importance of for example teachers taking careful consideration when they use fiction books as well as film - in an attempt to create contrasting images to undemocratic conditions, as the Swedish school curriculum requires. In addition to the experiences conveyed in the conversations, I have also seen examples of how people in conversation about literature can position themselves as, e. g., a booklover, a guy or as enlightened. A discursive reception analysis also offers insights into how booktalk reception is done. Detailed analyses of conversations about books provide opportunities to study the connection between fiction and life. In this way, our knowledge of literature in practice increases, allowing us to address questions such as: How is literature used to create ourselves and position others, to portray us as good or well-read, as belonging to the cultural elite or as not being snobbish? How can discussions about literature be used to quarrel, flirt, make friendships, etc.?

In an ongoing research project, I have made observations using video and/or audio recorders to collect sequences of naturally occurring reception of theater and films ( 44 theatre goers in 15 conversations in the pause of three theatre plays and 39 
cinema goers in 16 conversations after seeing 14 different films, in groups of two to ten people). That project picks up the challenge »to lead empirical study of literature into the next stage of its existence« (Dixon/Bortolussi 2011, 64). Going to the theater and movies are both social activities that provide more "natural « reception than book reading, which is often carried out in solitude (Eriksson Barajas 2014a; Eriksson Barajas 2014b). One preliminary finding from my project is that theatre and cinema audiences talk about literary phenomena, such as temporality and pace, in multiparty conversations about the play and the film they have seen, however, generally without using literary notions as such (Eriksson Barajas 2014b).

Using a discursive reception research approach, the field of reception research gains a way to adequately analyze conversations about literature (and other aesthetic products), as well as an opportunity to study how the reception is done and how literature is used. Discursive psychology, in turn, gains an opportunity to »dementalize« a practice that has previously been surrounded by a strict cognitivist paradigm. Literature and other aesthetics products, like film and theater, often deal with existential questions. In this way, conversation data on aesthetic reception provides a greater breadth of such content than other natural conversation data.

Reception research could be extended to investigate "naturally« occurring spontaneous reception, for example in chat rooms, on websites and other venues where people discuss books and movies privately, outside the framework of the school. It would be interesting to record the conversations that occur among the bookcases in libraries or among the bookshelves at a bookstore. Heather Bailey and Jeffrey M. Zacks (2011, 72) argue for the use of longer, naturalistic narratives, instead of short, laboratory-contrived »textoids" and they point out that: »If you want to understand how people really read then, at some point, you have to study how people really read." In line with Geoff Hall (2008) and Gerald C. Cupchik (2011), I would like to further suggest not only researching naturalistic texts but also naturalistic reading situations (Eriksson Barajas 2007). Future studies of other child and adult everyday practices around fiction are welcome.

\section{References}

Allington, Daniel/Joan Swann, Researching Literary Reading as Social Practice, Language and Literature 18:3 (2009), 219-230.

Bailey, Heather/Jeffrey M. Zacks, Literature and Event Understanding, Scientific Study of Literature 1:1 (2011), 72-78.

Chambers, Aidan, Tell Me: Children, Reading and Talk [1993], Stroud 1999.

Cochran-Smith, Marilyn, The Making of a Reader, Norwood, NJ 1994.

Cowley, Joy, The Silent One, London 1981.

Cupchik, Gerald C., The Future of an Allusion, Scientific Study of Literature 1:1 (2011), 173-181. 
Davies, Bronwyn, Frogs and Snails and Feminist Tales: Preschool Children and Gender, Sydney 1989.

Dixon, Peter/Marisa Bortolussi, The Scientific Study of Literature. What Can, Has and Should Be Done, Scientific Study of Literature 1:1 (2011), 59-71.

Edwards, Derek, Discourse and Cognition, London 1997.

Edwards, Derek, Extreme Case Formulations: Softeners, Investment, and Doing Nonliteral, Research on Language \& Social Interaction 33:4 (2000), 347-373.

Edwards, Derek/Jonathan Potter, Discursive Psychology, London 1992.

Ekholm, Lasse, Smuggelkatten, Stockholm 1990.

Eriksson, Katarina, Booktalk Dilemmas: Teachers' Organisation of Pupils' Reading, Scandinavian Journal of Educational Research 46:4 (2002), 391-408 (Eriksson 2002a).

Eriksson, Katarina, Life and Fiction. On Intertextuality in Pupils' Booktalk (Linköping studies in arts and science 251), Linköping 2002 (Eriksson 2002b).

Eriksson, Katarina/Karin Aronsson, Building Life World Connections During School Book talk, Scandinavian Journal of Educational Research 48:5 (2004), 511-528.

Eriksson, Katarina/Karin Aronsson, ১We're Really Luckys: Co-Creating $>$ Us School Book talk, Discourse \& Society 16:5 (2005), 719-738.

Eriksson Barajas, Katarina, Diskursiv receptionsforskning - En väg till kunskap om berättelsen i vardagen, in: J. Cromdal et al. (ed.), Den väsentliga vardagen: Några diskursanalytiska perspektiv på tal, text och bild, Stockholm 2007, 133-148.

Eriksson Barajas, Katarina, Beyond Stereotypes? Talking About Gender in School Booktalk, Ethnography and Education 3:2 (2008), 129-144.

Eriksson Barajas, Katarina, How to (or Not to) Research Reception of Fiction in Public Spaces: Methodological Reflections, paper presented at the 14th conference of the International Society for the Empirical Study of Literature and Media, Turin, Italy 21-15 July 2014 (Eriksson Barajas 2014a).

Eriksson Barajas, Katarina, Pace as a measure of aesthetic value, On-line Proceedings of the Annual Conference of the Poetics and Linguistics Association (PALA) 2014, http://www. pala. ac.uk/uploads/2/5/1/0/25105678/eriksson_barajas_k.pdf (Eriksson Barajas 2014b).

Eriksson Barajas, Katarina/Karin Aronsson, Avid Versus Struggling Readers: Co-Construed Pupil Identities in School Booktalk, Language and Literature 18:3 (2009), 281-299.

Fish, Stanley, Is There a Text in This Class? The Authority of Interpretive Communities, Cambridge, MA 1998.

Hall, Geoff, Empirical Research into the Processing of Free Indirect Discourse and the Imperative of Ecological Validity, in: Sonia Zyngier et al. (ed.), Directions in Empirical Literary Studies, Amsterdam 2008, 21-34.

Hepburn, Alexa/Jonathan Potter, Discourse Analytic Practice, in: C. Seale et al. (ed.), Qualitative Research Practice, London 2004, 180-196.

Hepburn, Alexa/Sally Wiggins, Developments in Discursive Psychology, Discourse \& Society 16:5 (2005), 595-601.

Hermes, Joke, Reading Woman's Magazines: An Analysis of Everyday Media Use, Cambridge 1995.

Holub, Robert C, Reception Theory: A Critical Introduction, London 1984.

Howard, Judith A./Carolyn Allen, Making Meaning: Revealing Attributions through Analyses of Readers' Responses, Social psychology quarterly 52:4 (1989), 280-298.

Iser, Wolfgang, The Act of Reading: A Theory of Aesthetic Response, London 1978. Jauß, Hans Robert, Toward an Aesthetic of Reception, Brighton 1982. 
Mankell, Henning, Secrets in the Fire, Crows Nest 2000.

Molloy, Gunilla, Läraren-Litteraturen-Eleven. En studie om läsning av skönlitteratur på högstadiet [The Teacher - the Literature - the Student. A Study of Reading of Fiction in Secondary School], Stockholm 2002.

Onions, Charles T. (ed.), The Oxford Dictionary of English Etymology, Oxford 1966.

Potter, Jonathan, Discourse Analysis, in: Melissa A. Hardy/Alan Bryman (ed.), Handbook of Data Analysis, London 2003, 607-624.

Potter, Jonathan, Making Psychology Relevant, Discourse \& Society 16:5 (2005), 739-747.

Potter, Jonathan/Peter Stringer/Margaret Wetherell, Social Texts and Context: Literature and Social Psychology, London 1984.

Potter, Jonathan/Margaret Wetherell, Discourse and Social Psychology: Beyond Attitudes and Behaviour, London 1987.

Rydin, Ingegerd, Making Sense of Tv-Narratives: Children's Readings of a Fairy Tale (Linköping studies in arts and science 142), Linköping 1996.

Sacks, Harvey/Emanuel A. Schegloff/Gail Jefferson, A Simplest Systematics for the Organization of Turn-Taking for Conversation, Language 50:4 (1974), 696-735.

Svensson, Jón/Georg Telemann, Nonni Och Manni, Unterägeri 1989.

Swann, Joan/Daniel Allington, Reading Groups and the Language of Literary Texts: A Case Study in Social Reading, Language and Literature 18:3 (2009), 247-264.

Van Peer, Willie, Introduction, Scientific Study of Literature 1:1 (2011), 1-5.

\section{Appendix A: Transcription symbols}

Transcription symbols are mainly based on conversation analysis and discursive psychology (Edwards 1997). Square brackets mark the start and end of overlapping speech; underlining, emphasis, with the extent of underlining within individual words locating the emphasis; bold, pronunciation differs from surrounding speech, e. g. irony, theatrical; CAPITALS, mark speech that is obviously louder than surrounding speech; ${ }^{\circ} .{ }^{\circ}$, quieter speech; $(n)$, a pause, with $n$ indicating the time in seconds; (.), micro pause; ((Text)), transcriber's comments;:, Prolongation of preceding vowel; ><, speeded-up talk; <>, slower talk; =, immediate »latching " of successive talk; -, utterance interrupted or ebbed away; (...), talk has been omitted from a data excerpt; (text), uncertain interpretation; (x) (xx), inaudible word or words; hehe, laughter. 


\section{Appendix B: Swedish original excerpts}

\section{Excerpt 1}

J: Du läser inte särskilt mycket, va?

E: Nej, det gör jag inte.

J: Känner du några killar som gör det?

E: Hm, nej, ingen som jag vet som läser mycket. Nej, faktiskt inte. Det finns dom som läser mer än mig, men inte så där överdrivet mycket.

$\mathrm{J}: \mathrm{mm}$, är det inte killigt att läsa böcker?

$\mathrm{E}$ : Jag vet inte. Det kanske inte lockar killar att läsa böcker.

J: Vad är det som lockar killar istället då?

E: Eh, det är dataspel och datorer och olika idrotter och sånt.

\section{Excerpt 2}

1. MARY: så att de- det var många tankar som gick igenom hennes huvud och ibland så satte hon sig och så drog hon den här filten över huvudet och vägrade äta och ville inte svara (.) vad tror ni att hon gjorde det för?

2. Sten: ja hon tr- hon tyckte att det var hennes fel att Maria ((hennes syster.)) var död

3. Bo: onon ville va osynlig ${ }^{\circ}$

4. MARY: ja, Bo vad säger du då?

5. Bo: hon ville va osynlig

6. $\rightarrow$ MARY: och det var nå såna här stunder när hon-vi brukar säga man är deprimerad, man vill inte prata med nån (.) när ni inte vill prata med nån, när ni känner att usch! nu är allting så jobbigt hur gör ni?

7. Dora: Jag sitter tyst

8. Rut: stänger in sig i rummet

9. Sten: Det kan inte jag

10. MARY: du kan inte

11. $\rightarrow$ Sten: vi har en massa sladdar från mitt rum så det går inte och stänga dörr’n

\section{Excerpt 3}

1. SUE: skulle nån utav er vilja vara Anna? vara som Anna?

2. ((Sara och Mia räcker upp handen. Julia räcker också upp handen.))

3. $\rightarrow$ SUE: ja alla tjejerna

4. Mia: hon har en så snäll pappa

5. Sara: jag skulle också vilja vara som Anna ((Småskrattande.)) 


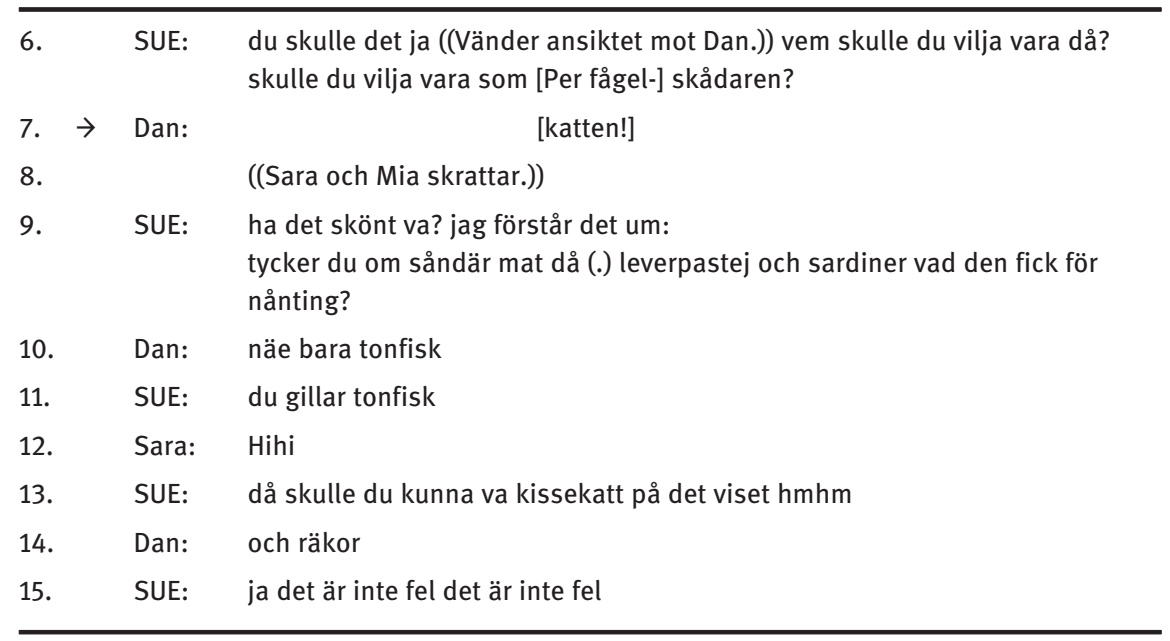

\section{Excerpt 4}

\begin{tabular}{|c|c|c|}
\hline $\begin{array}{l}1 . \\
2 . \\
3 .\end{array}$ & ALLAN: & 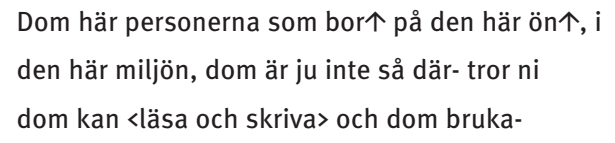 \\
\hline 4. & Pia: & Azaki- ki kan dä’ \\
\hline $\begin{array}{l}5 . \\
6 .\end{array}$ & ALLAN: & $\begin{array}{l}\text { Ja, just det. Men han är nästan ensam om det, } \\
\text { va? }\end{array}$ \\
\hline 7. & Flera: & Um \\
\hline 8. & ALLAN: & (3) Men dom som bor där på ön, dom har mest \\
\hline 9. & & Bara sett det som finns där. \\
\hline 10. & Klas: & $\mathrm{Ja}$ \\
\hline $\begin{array}{l}11 . \\
12 . \\
13 .\end{array}$ & ALLAN: & $\begin{array}{l}\text { Dom har sina egna föreställningar dom kan } \\
\text { aldrig läsa om några andra har- dom träffar } \\
\text { ganska sällan några andra människor. }\end{array}$ \\
\hline 14. & Pia: & Um \\
\hline 15. & ALLAN: & Eller hur? \\
\hline 16. & Klas: & $\mathrm{Ja}$ \\
\hline $\begin{array}{l}17 . \\
18 .\end{array}$ & ALLAN: & $\begin{array}{l}\text { Så då kan det vara lite svårt för dom och tänka } \\
\text { på andra sätt. }\end{array}$ \\
\hline
\end{tabular}




\section{Excerpt 5}

\begin{tabular}{|c|c|c|}
\hline 1. & $\mathrm{~T}:$ & -kanske lite mer i helgen för \\
\hline 2. & & Då har man mera ti:d ((förklarar hur man \\
\hline 3. & & ska läsa över tid)) \\
\hline 4. & Vicky: & ${ }^{\circ} j a$, kanske två kapitel ${ }^{\circ}$ \\
\hline 5. & Sonja: & $>^{\circ}$ Jag kan läsa ut hela boken i dag. ${ }^{\circ}<$ \\
\hline 6. & $\mathrm{~T}:$ & ((paus)) Känner du dig sugen? ((vänlig \\
\hline 7. & & röst; vänder sig mot Sonja)) \\
\hline 8. & Sonja: & ${ }^{\circ} \mathrm{Mhm}^{\circ}(($ nickar $))$ \\
\hline 9. & Children: & ((småskrattar vänligt)) \\
\hline
\end{tabular}

